\title{
"LE DERNIER MOT", DE MAURICE BLANCHOT, OU A TORRE DE BABEL Davi Andrade PIMENTEL ${ }^{1}$
}

Caligula

“Je ne t'ai pas encore donné la parole. À raison de nos besoins, nous ferons mourir ces personnages dans l'ordre d'une liste établie arbitrairement. À l'occasion, nous pourrons modifier cet ordre, toujours arbitrairement. Et nous hériterons." - CAMUS, 1958: 56

RESUMO: Este artigo analisa a narrativa "Le dernier mot", do escritor francês Maurice Blanchot, a partir de dois mitos: o mito bíblico da Torre de Babel e o mito grego das Bacantes. Desse diálogo, destacam-se três questões que são fundamentais no desenvolvimento deste artigo: a questão da palavra babélica, a questão do retorno à origem e, por fim, a questão do primitivo/criança. Essas questões têm como pressuposto teórico, além dos textos ensaísticos de Blanchot, textos de Jacques Derrida, Friedrich Nietzsche e Jean-Luc Nancy.

PALAVRAS-CHAVE: Maurice Blanchot, Torre de Babel, Bacantes, origem, linguagem.

${ }^{1}$ Pós-doutorando da Universidade Federal Fluminense. Bolsista Faperj. E-mail: davi_a_pimentel@yahoo.com.br 
RÉSUMÉ: Cet article analyse le récit «Le dernier mot» de l'écrivain français Maurice Blanchot, à partir de deux mythes: le mythe biblique de la Tour de Babel et le mythe grec des Bacchantes. De ce dialogue ressortent trois questions qui sont essentielles à l'élaboration de cet article: la question du mot babellique, la question du retour à l'origine et, enfin, la question du primitif/enfant. Ces questions ont comme hypothèse théorique, outre les essais de Blanchot, des textes de Jacques Derrida, Friedrich Nietzsche et Jean-Luc Nancy.

MOTS-CLÉS : Maurice Blanchot, Tour de Babel, Bacchantes, origine, langage.

Do alto de seu trono, observando a construção da torre que objetivava alcançar os mais vastos campos celestes, Deus, a fim de castigar a prepotência de sua criatura, disse: "Eles são um só povo e falam uma só língua, e começaram a construir isso. Em breve nada poderá impedir o que planejam fazer. Venham, desçamos e confundamos a língua que falam, para que não entendam mais uns aos outros." (GÊNESIS, v.11.6: 24-5) ${ }^{2}$. Aos construtores de Babel, a punição lançada é dirigida à língua, ou melhor, à linguagem, meio pelo qual os homens buscavam nomear, interagir, comunicar, confabular, manipular, aterrorizar e matar uns aos outros. Com o castigo, a linguagem, instrumento dos mais privilegiados na ocupação do homem no mundo, se fez plural. A audição não mais captava os sons daquele que, momentos antes, se comunicava conosco. A palavra ecoava sem entendimento entre os homens, não havia mais ordem ou normas. A linguagem, dom divino ofertado aos homens, foi reavida por Deus.

O Senhor, tendo soprado na boca do homem o dom da palavra, retira-lhe o entendimento, a sua funcionalidade. Agraciados são aqueles que pela boca pronunciam palavras e das palavras se ergue o entendimento: "Dando seu nome, dando todos os nomes, o pai estaria na origem da linguagem e esse poder pertenceria de direito a Deus o pai. E o nome de Deus o pai seria o nome dessa origem das línguas. Mas é também esse Deus que [...] anula o dom das línguas, ou ao menos o desune, semeia a confusão entre seus filhos e envenena o presente" (DERRIDA, 2002: 14, grifos meus). O castigo descentrou os homens. A única língua do mundo se tornou plural, nada havia de mais estranho do que aqueles homens perdidos entre si na planície de Sinear.

A partir da babelização da linguagem, cada homem passou a errar pelos confins mais inauditos do mundo. Já cansados, os homens se fixaram em locais diferentes, ensinando aos seus descendentes a particularidade da língua primeira que a eles foi destinada. Assim se fez a humanidade. Contudo, em sua aparente estabilidade, o homem ainda continua a errar, seja no aspecto nômade da palavra, seja na dificuldade em trazer para junto de si uma definição mais completa do mundo, seja

${ }^{2}$ As citações dos textos bíblicos foram retiradas da edição Bíblia de Estudo NVI, 2003. A partir deste ponto, as citações bíblicas serão indicadas apenas pelo livro correspondente, indicação do versículo e número da página. 
na impossibilidade de voltar à origem. Em seu afã de traduzir o mundo, de dar traduzibilidade ao que observa e constata no mundo, o homem intenta de modo inconsciente, talvez, reestruturar o entendimento original, a ideia primeira, a linguagem que o originou. Não por menos, grande parte dos estudos realizados pelo homem retorna aos aspectos anteriores da humanidade, recorrentemente se dirige ao passado para dele retirar um novo ponto de vista.

Questões atuais são e serão sempre questões já levantadas no passado em menor ou maior intensidade. O passado nos assombra, pois é nele que consta uma das nossas primeiras faltas: a tentativa de nos igualar a Deus/Natureza. Na verdade, não se olha para frente sem olhar seguidas vezes para trás: "Nietzsche (ou Zaratustra) disse com perfeita clareza que, onde o querer se torna liberador, choca-se com o passado." (BLANCHOT, 2007: 110). Desse modo, o cientificismo humano nada mais seria do que um retorno à integridade perdida, um pedido de desculpas para um Deus que, mesmo passados tantos séculos, ainda não perdoou o homem.

Desde a queda de Babel, nós ainda carregamos parte de seus escombros. De sua ruína não podemos nos esquecer, uma vez que a cada instante em que a palavra é proferida o castigo reacende, novamente reiterado, expondo aos homens a falta de seus antepassados, falta antiga e atual, falta que permanece na língua, na arbitrariedade do signo linguístico, confirmando o desentendimento secular entre o Criador e suas criaturas.

É a partir da palavra, em qualquer língua em vigor, que constatamos internamente uma confusão dos signos, uma queda das significações, a ruína do sentido. Nada há de legítimo na união de um significante e de um significado. Nada significa de fato, o que é proferido não é a palavra com sentido, mas a palavra-Babel, palavra-castigo, palavra-confusão. E mesmo com os esforços dos homens, cada um a sua maneira, de tornar objetivo aquilo que não pode ser objetivado, a linguagem, ainda assim, se mantém babélica: "Confiante na linguagem entendida como o desafio provocante que nos foi confiado do mesmo modo que lhe fomos confiados." (BLANCHOT, 1980: 202)3.

A linguagem literária, se comparada à linguagem cotidiana, resguarda os escombros de Babel de uma maneira singular, pois ela não deseja omitir sua origem provinda da confusão das línguas. Ela, ao contrário, reafirma a posição de ruína, de material sem centro, disposta a perpetuar o contínuo de vozes que ao longo da história se fizeram presentes no constructo plural denominado literatura. A literatura é caos, é queda, é pluralidade. Longe de parecer apenas um mito da origem das línguas, Babel é a metáfora do descentramento, do que não pode ser acabado, do que não pode ser concluído: verdade jogada ao chão por uma força maior. Babel, por muitas analogias que poderíamos aqui desenvolver, é, também, a metáfora da pluralidade literária: “A ‘torre de Babel' não configura apenas a multiplicidade irredutível das línguas, ela exibe um não-acabamento, a impossibilidade de completar, de tota-

3 As traduções dos trechos das obras em francês citadas ao longo deste artigo são de minha autoria. "Confiant dans le langage entendu comme le défi provocant qui nous a été confie de même que nous lui avons été confiés.”. 
lizar, de saturar, de acabar qualquer coisa que seria da ordem da edificação, da construção arquitetural, do sistema e da arquitetônica.” (DERRIDA, 2002: 11-2).

Nas narrativas blanchotianas, a confusão das línguas ressurge para, mais uma vez, findar com a queda da torre. Uma segunda Babel, talvez. Em "Le dernier mot”, narrativa presente em Le ressassement éternel, é na vinda da noite que novamente Babel sucumbirá. A narrativa de "Le dernier mot" já se apresenta ao leitor como uma narrativa do pós-castigo divino e antes da queda da torre, em um entremeio no qual os personagens que erram pelo texto blanchotiano não conseguem mais compreender uns aos outros. A palavra de entendimento está perdida, tudo está prestes a sucumbir: "As palavras que ouvi naquele dia soavam mal aos meus ouvidos, na mais bela rua da cidade." (BLANCHOT, 1983: 57)4.

A linguagem não pode mais conduzir o narrador a uma comunicação entre seus pares. Não há mais a relação de diálogo do entendimento, mas diálogo que gera o disparate e a discordância. A linguagem se torna perigosa, um risco a se correr: “- Sua linguagem pouco me agrada. Você está seguro de suas palavras? / - Não, disse encolhendo os ombros, como eu poderia estar seguro? É um risco a se correr." (BLANCHOT, 1983: 57)5. Em um espaço no qual a língua perdeu a sua funcionalidade, qualquer palavra é palavra a ser mensurada, a ser revestida de cuidados. O dito passará a ser interdito, aquilo que não pode ser dito ou redito. A linguagem do narrador se transforma em arma contra ele próprio, por isso o risco a se correr, por isso o perigo ao falar.

Em uma cidade onde a linguagem não perpetua mais um sentido, o narrador ainda buscava nesse espaço do caos a palavra de ordem, a palavra de instrução. Mas, instrução, ordem, para qual finalidade? “—Qual é, pois, a palavra de ordem? / - Eu a confiaria com muito prazer a você, mas eis que, é que justamente, hoje, ainda não consegui escutá-la." (BLANCHOT, 1983: 57)6 . Essa cidade não possui um nome, não carrega a propriedade de um nome, sendo, por assim dizer, uma cidade qualquer. Nesse território anônimo, algo de misterioso, de não pronunciável, circunda o narrador. Fatos absolutamente estranhos lhe dizem respeito. Ações que se transformam em ritos de alguma religião antiga. Ritos obscuros, sonhos revelados à beira de um caos que se formou nas circunvizinhanças da cidade sem nome. Cidade que, por si mesma, é uma cidade do porvir, cidade apocalíptica, cidade do castigo. Desse modo, como exigir dos passantes, dos errantes, a palavra de ordem? E mesmo que ainda houvesse uma palavra de ordem, como imputá-la em um espaço onde a palavra se faz desnecessária, onde o que prevalece é o arbitrário, o sentido múltiplo da língua? Aqui, o que ressoa é a desordem festiva do dionisíaco. Assim, exigir a ordem onde não há mais a lei da concordância, da união, é recair no erro, é tentar uma volta impossível à origem da falta: "Por que ninguém me

4 “Les paroles que j'entendis ce jour-là sonnaient mal à mes oreilles, dans la plus belle rue de la ville.'

5 "- Votre langage ne me plaît qu'à moitié. Etes-vous sûr de vos paroles? / - Non, dis-je en haussant les épaules; comment pourrais-je en être sûr? C'est un risque à courir.”

6 “-Quel est donc le mot d'ordre? / - Je vous le confierais volontiers, me répondit-il; mais voilà, c'est que justement, aujourd'hui, je n'ai pas encore réussi à l'entendre." 
comunicou a palavra de ordem? - É que não existe mais palavra de ordem, ele disse sem levantar a cabeça" (BLANCHOT, 1983: 62)7.

Em sua busca pela palavra de ordem que o guiasse através do inferno babélico, o narrador interpelava os passantes sobre o paradeiro de uma mulher chamada Sophonie, mulher que, segundo ele, poderia estar na biblioteca. Em sua procura, dispersado por um grupo de crianças, o personagem avista um edifício e lá pergunta a direção exata da biblioteca. O zelador do prédio, ao encontrá-lo, acredita que ele seja o último de alguma lista de presença cuja reunião e temática têm uma importância alarmante: "- Como? disse o zelador com um ar de pavor. Seria você o último? Suba rápido, o momento é esse.” (BLANCHOT, 1983: 58) ${ }^{8}$. Ele seria a última esperança para reverter o castigo? Ou, quem sabe, a última centelha da ordem em meio ao caos? Com muita rapidez o zelador conduz o personagem a uma pequena sala escura na qual se podia perceber em seu centro um livro.

Na sala, o narrador, pensando estar sozinho, se aproxima do livro. Ao tentar folhear algumas de suas páginas, uma mulher, que se encontrava na parte escura do diminuto recinto, enrolada em pequenos andrajos, grita. $\mathrm{O}$ narrador, assustado, diz: “- Eu não a tinha percebido, ele disse. A minha presença a incomoda? / - De modo algum, mas, na minha idade, não estou habituada a visitas." (BLANCHOT, 1983: 58)9. Sem nenhum traço de reconhecimento prévio, sem nem mesmo uma palavra, o narrador identifica na mulher que acabara de gritar quem procurava: Sophonie ${ }^{10}$. Ela apanha o livro, que continuava no centro da sala, e começa a arrancar as suas folhas, entregando algumas delas ao narrador. Em sua atitude pouco convencional, ao violar o livro, possivelmente, um livro importante, Sophonie afasta qualquer elemento valorativo, verídico ou divino de seu texto, removendo de sua estrutura discursiva todo e qualquer vestígio que possa relacioná-lo a outros livros que têm como base os princípios da verdade e do saber - naquele momento, nada poderia reverter o castigo lançado aos moradores da cidade, nenhum saber poderia auxiliá-los na confusão das línguas.

Entretanto, se o livro destruído por Sophonie não sustenta nenhum saber, se a sua violação marca a perda de qualquer referência a um texto mais antigo - e, por que não, sagrado - é preciso destacar que a estrutura de seu discurso é praticamente a mesma que encontramos nos textos bíblicos e, principalmente, a história

\footnotetext{
7 “Pourquoi ne m'a-t-on pas communiqué le mot d'ordre? - C'est qu'il n'y a plus de mot d'ordre, dit-il sans lever la tête"

8 “- Comment? dit le concierge d'un air d'effroi. Seriez-vous le dernier? Montez vite, il n'est que temps."

9 “- Je ne vous avais pas aperçue, lui dis-je. Est-ce que ma présence vous incommode? / — Pas du tout, mais, à mon âge, je n'ai pas l'habitude des visites.”

10 A estrutura do nome da personagem Sophonie nos remete de imediato à leitura do livro do profeta Sofonias, Livro de Sofonias, que consta na Bíblia Sagrada, no qual Deus, através do profeta, diz que destruirá todas as torres que intentam proteger o homem, que intentam resguardá-lo de suas faltas: "O dia do Senhor será amargo; até os guerreiros gritarão. Aquele dia será um dia de ira [...] dia de toques de trombeta e gritos de guerra contra as cidades fortificadas e contra as torres elevadas." (SOFONIAS, v. 1.146: 1.565, grifos meus). Percebe-se que tanto no livro do Gênesis quanto no Livro de Sofonias, temos a figura do Pai ciumento, como bem lembra Derrida, em Torres de Babel, frente à deserção de seus filhos em adorarem um outro pai ou outros ídolos, como, por exemplo, o próprio homem: "Não se pode então falar de um ciúme de Deus? Por ressentimento contra esse nome e esse lábio únicos dos homens, ele impõe seu nome, seu nome de pai; e dessa imposição violenta enceta a desconstrução da torre como da língua universal e dispersa a filiação genealógica. Ele rompe a linhagem.” (DERRIDA, 2002: 18).
} 
que será lida em voz alta pelo narrador se aproxima bastante das histórias com um fundo moral que encontramos nas Escrituras Sagradas, como pode ser observado na leitura realizada pelo personagem:

- É um excerto do discurso sobre o terceiro Estado, eu disse depois de ter olhado as folhas. Escute a leitura dele. "Houve um tempo em que a linguagem cessou de relacionar as palavras entre si segundo relações simples e tornou-se um instrumento tão delicado que se proibiu o seu uso pela grande maioria da população. Mas, os homens, carecendo naturalmente de sabedoria, e o desejo de estarem unidos por laços seguros não lhes deixando nenhuma paz, fizeram pouco dessa interdição. Diante de tal loucura, as pessoas sábias decidiram não mais falar. Elas, a que nada estava proibido e que sabiam se exprimir, guardaram doravante o silêncio. Os sábios pareciam somente ter tomado conhecimento das palavras para melhor ignorá-las e, as associando ao que existe de mais secreto, desviaram as palavras de seu curso natural." (BLANCHOT, 1983: 59-60) ${ }^{11}$

No momento em que a palavra perde a sua funcionalidade, função já arruinada desde a queda de Babel, a prioridade é guardar o silêncio e desinvestir a palavra de sua pretensa utilidade - refiro-me à nomeação. No entanto, como ocorre em grande parte das narrativas bíblicas, o homem sempre deseja saber mais, conquistar mais, nomear mais, invadir mais, se igualar cada vez mais ao Pai. E esse desejo sempre o leva à desobediência, assim foi com Eva, com os construtores de Babel e com muitos outros: "Como sempre, é o desejo que engendra a falta. Ele é a falta." (DERRIDA, 1999: 197) ${ }^{12}$. O livre arbítrio tem dessas coisas.

Em uma leitura mais atenta, caso não houvesse a desobediência humana, não haveria a necessidade de impor a força divina. Deus continuaria a ser uma presença, claro, mas uma presença distante. Já com a infração cometida pelo homem, a presença divina arrebata o maior número de crentes através da exemplificação, do castigo e da expiação. A presença tão dramática de Deus provém da falta e da insubordinação de suas criaturas. O texto lido pelo narrador blanchotiano pode figurar como um texto de exemplo, um texto cuja moral seria a de nunca se opor à

\footnotetext{
${ }^{11}$ “- C'est un extrait du discours sur le troisième Etat, dis-je après avoir regardé des feuilles. Ecoutez-en la lecture. 'Il y eut un temps où le langage cessa de lier les mots entre eux suivant des rapports simples et devint un instrument si délicat qu'on en interdit l'usage au plus grand nombre. Mais, les hommes manquant naturellement de sagesse et le désir d'être unis par des liens défendus ne leur laissant aucune paix, ils se monquèrent de cette interdiction. Devant une telle folie, les personnes raisonnables décidèrent de ne plus parler. Elles à qui rien n'était interdit et qui savaient s'exprimer, gardèrent désormais le silence. Elles semblaient n'avoir appris les mots que pour mieux les ignorer et, les associant à ce qu'il y a de plus secret, elles les détournèrent de leur cours naturel.”

12 "Comme toujours, c'est le désir qui engendre la faute. Il est la faute."
} 
onipotência divina sob risco de ser castigado mais uma vez com a perda da funcionalidade da linguagem.

Contudo, o caráter moral do texto lido pelo narrador se apresenta inútil quando o castigo já foi lançado, quando a língua perdeu a sua característica básica, a comunicação, por isso a atitude de Sophonie em destruir o livro, pois ele não teria mais utilidade em meio ao caos que se instalou na cidade - a sua proximidade com os escritos bíblicos ficaria restrita à estrutura do discurso e não ao conteúdo, pois não há saber, verdade ou moral que possa reverter o castigo lançado à segunda Babel. Infelizes são aqueles que ainda continuam a falar e a desrespeitar a lei dos mais sábios. Acreditem, falar é erro, é perdição. Porém, o narrador, que deveria buscar o silêncio, ainda intenta a palavra de ordem, ainda clama pela seguridade obtida pela palavra: "Senhor, não mereço receber-te debaixo do meu teto. Mas dize apenas uma palavra, e o meu servo será curado.” (MATEUS, v. 8.8: 1.629, grifos meus).

A força atribuída à palavra divina, palavra da ordem e do caos, palavra que concede a morte e a vida, é cobiçada pelo personagem blanchotiano ao desejar, por um momento, a palavra de ordem que traria novamente a certeza das coisas, pois se o servo foi curado, o mundo também o seria: “'Ó cidade, disse rezando, já que logo não poderei mais por minha linguagem me comunicar com você, deixeme até o fim gozar das coisas às quais as palavras respondem se elas se quebram." (BLANCHOT, 1983: 65) ${ }^{13}$.

O narrador, ao suplicar à cidade, está suplicando à Natureza e, por conseguinte, suplicando a Deus, o Senhor da terra. Contudo, súplicas arrebatadas pelo vento não há diálogo possível. Com o término da leitura realizada pelo personagem, é chegado o momento de Sophonie ler o conteúdo presente nas folhas que estavam em seu poder; todavia, não podendo lê-las, ela admite a sua falta e decide renunciar a sua leitura: "- Eu somente tenho algumas linhas para ler, disse a velha do seu modo; mas, após ter começado a soletrar de maneira insatisfatória a palavra naufrágio, ela acrescentou: Desculpe-me, devo, aqui, renunciar." (BLANCHOT, 1983: 60) ${ }^{14}$.

Por sua falta, Sophonie lhe entrega uma pequena lembrança: "Ela se vestiu rapidamente e, mexendo num de seus bolsos, mostrou uma imagem representando a cabeça de uma criança. / - Aceite essa lembrança, não tenho nada mais para lhe dar para compensar o mal que lhe faço." (BLANCHOT, 1983: 60) ${ }^{15}$. A imagem da criança está associada à imagem do primitivo, estado anterior da linguagem verbal, linguagem alfabética - linguagem que concede ao homem a característica de ser homem, pois aquele que fala se autonomeia eu e nomeia o outro e as coisas que o cercam.

${ }_{13}$ “'O ville, dis-je en priant, puisque bientôt je ne pourrai plus par mon langage communiquer avec vous, laissez-moi jusqu'à la fin jouir de ces choses auxquelles les mots répondent s'ils se brisent."”

14 “- Je n'ai que quelques lignes à lire, dit la vieille femme à son tour; mais, après avoir commencé à épeler maladroitement le mot naufrage, elle ajouta: Excusez-moi, je dois y renoncer."

${ }_{15}$ "Elle se rhabilla rapidement et, fouillant dans un de ses poches, montra une image représentant la tête d'un enfant. / - Acceptez ce souvenir, je n'ai rien d'autre à vous donner pour compenser le tort que je vous fais.” 
Na particularidade da linguagem que faz do homem um ser da razão, algo tende a tornar impreciso o princípio da racionalidade humana, princípio que o distingue dos demais animais. A criança seria essa falta de razão que obseda o homem da razão. O infante é, desde o nascimento, uma duplicata do homem adulto, porém, uma duplicata que se distingue de sua fase adulta exatamente por não nascer com a linguagem, como se a linguagem, por ser adquirida após a sua vinda ao mundo, fosse um elemento a ele exterior, quase um acessório em sua locomoção pelo mundo, embora esse acessório seja de extrema necessidade à construção da ideia de mundo e de homem.

A criança, como imagem mais próxima de nossos antepassados, pode ser compreendida como o mais próximo do ser humano antes da nomenclatura ser humano. O infante é, possivelmente, a prefiguração do primitivo. A criança, como não se comunica por palavras no início de sua vida, reconhece o mundo sinestesicamente, através de gestos, de balbucios, de gritos, como o restante dos animais que dividem conosco o globo terrestre. É certo que o nosso cérebro se desenvolveu mais rapidamente, caso o comparemos com o cérebro de outros animais. Mas é certo, também, que determinados traços do primitivo ainda nos habitam, sendo uma lembrança perpassada de geração em geração através da imagem da criança. Imagem do infante que é o primitivo prefigurado - primitivo que será logo esquecido quando a criança se expuser à linguagem.

Sophonie, ao oferecer a imagem da cabeça de uma criança, cabeça sem corpo, ou melhor, cabeça que não pode ser reconstituída ao seu corpo, assinala a impossibilidade da ambição do personagem em voltar ao seu antepassado primitivo, antes-Babel, na tentativa de reparar a falta, de reconstruir a primeira nação, a primeira língua. Desejo impossível. O primitivo vislumbrado na criança não se circunscreve apenas à questão da linguagem, mas também à questão do olhar.

O narrador, ainda perdido em sua busca pela palavra de ordem, não aceita e nem compreende a lembrança que a personagem quis lhe oferecer. Ao sair do edifício, ele se dirige à multidão que se aglomerava no lado de fora. Nas ruas, acompanhado mais uma vez por Sophonie, o personagem ouve dela o último golpe sofrido pela ordem. A biblioteca foi destruída, o que ratificaria, uma vez por todas, a babelização da linguagem: "Você sabe da novidade? Não existe mais biblioteca. Cada um doravante lerá à sua maneira." (BLANCHOT, 1983: 63) ${ }^{16}$.

A biblioteca, edificação que guarda/protege os livros, é, do mesmo modo, uma edificação que resguarda, gerencia, rotula e dispõe do saber, sendo, portanto, uma instituição da ordem. A biblioteca é um território que procura preservar o poder da palavra literária, mesmo que o literário despreze esse poder a ele imputado. $\mathrm{Na}$ desordem da linguagem, o espaço da biblioteca, espaço da cultura do saber, se transforma em um lugar sem funcionalidade, logo, lugar a ser demolido, arruinado. A destruição da biblioteca passa a ser a metáfora da metáfora da dispersão das línguas, dispersão dos livros, dispersão do entendimento.

16 “'Connaissez-vous la nouvelle? Il n’y a plus de bibliothèque. Chacun désormais lira à sa guise.” 
Agora, cada um lê a sua maneira, pois, espalhados em diferentes territórios de linguagem, os homens não mais necessitarão de uma biblioteca que guarde o saber provindo da unidade de uma só língua, podendo, dessa forma, através da revolta pelo castigo, destruir tudo o que se refere à unidade, inclusive o próprio homem. A partir desse instante, os homens se entregam a uma espécie de animalidade festiva. Animalidade provinda da natureza:

De rua em rua, eu passeava com ela [Sophonie] em meio a restos de uma festa que as tochas em pleno meio-dia assinalavam. Um barulho imenso de gritos, obedecendo a um comando subterrâneo, levava de um só golpe toda a multidão ora para leste, ora para oeste. Em certos cruzamentos, a terra tremia e parecia que a multidão marchava sobre o vazio, que ela atravessava sobre uma passarela de vociferações. (BLANCHOT, 1983: 63) ${ }^{17}$

Sem mais o apelo das formas do apolíneo, a multidão se entrega desmedidamente às festividades do dionisíaco, obedecendo a um comando interno vindo da natureza, onde todos comungavam de um mesmo êxtase, marchando para o vazio e compartilhando de transes prolongados. Como não havia mais a língua para selar a comunicação, os homens faziam do corpo a linguagem necessária para se comunicarem em meio ao festival: "Sob a magia do dionisíaco torna a selar-se não apenas o laço de pessoa a pessoa, mas também a natureza alheada, inamistosa ou subjugada volta a celebrar a festa de reconciliação com seu filho perdido, o homem." (NIETZSCHE, 2007: 28). Em sua festividade, a multidão blanchotiana se assemelha aos homens que, seguindo as Bacantes, se deixavam invadir pelo signo de Dionísio - deus do vinho e da inspiração, festejado com grandes procissões, nas quais imperava a força da natureza.

Na narrativa "Le dernier mot", observo determinados pontos de convergência entre os trechos que confirmam a passagem do elemento festivo/dionisíaco em seu discurso- "eu passeava com ela em meio a restos de uma festa que as tochas em pleno meio-dia assinalavam. [...] Em certos cruzamentos, a terra tremia e parecia que a multidão marchava sobre o vazio" - com determinados trechos da tragédia As Bacantes, de Eurípedes, em que se ressaltam os momentos de transe/êxtase daqueles que seguiam Dionísio:

Dionisa-te/ com ramos de carvalho ou abeto!/ Entrama a veste nébrida/ furtacor/ com lanosas felpas brancas, / empunha/ a furiosa férula,/ pleno de pureza!/ Pan-Géia, a ter-

${ }_{17}$ "De rue en rue, je me promenai avec elle au milieu des débris d'une fête que signalaient des torches en plein midi. Un bruit immense de cris, obéissant à un commandement souterrain, portait d'un seul coup toute la foule tantôt à l'est tantôt à l'ouest. A certains carrefours, la terre tremblait et il semblait que la populace marchât sur le vide, qu'elle franchissait sur une passerelle de vociférations." 
ra toda em coro dança,/ tão logo Brômio monte adentro, monte adentro,/ tíaso-dançante/ adentre. [...] No solo/ flui o leite,/ flui o vinho,/ flui o néctar do mel./ Baco alça,/ fumo de incenso sírio,/ a tocha flâmea,/ deixa-a in-/ flamarse da férula./ À corrida e à dança,/ incita o coro errante,/ excita-o com seus gritos,/ lança no ar sinuosas tranças. (EURÍPEDES, 2010: 53-5, grifos meus)

Nas duas passagens destacadas, os elementos ritualísticos do dionisíaco são mencionados, como, por exemplo, o fogo presente nas tochas em pleno meio-dia e na tocha flâmea, que tanto simboliza a ardência dos corpos inebriados quanto a ardência do transe, do calor provindo das entranhas da natureza, fazendo com que a terra tremesse com a dança da multidão. Na celebração, a palavra é tornada elemento dispensável, corpo sem funcionalidade, material descartável: "Com destroços de palavras, como se da linguagem somente tivessem subsistido as formas de uma longa frase esmagada pelo pisoteado da multidão, alguém modulou um canto de uma mensagem que transparecia através de qualquer uivo. A mensagem era até o momento em que." (BLANCHOT, 1983: 63, grifos do autor) ${ }^{18}$. Até o momento em que, frase que necessita de um complemento para ser significante, para que seja possível a sua potencialidade temporal e discursiva.

No entanto, frase que se deixa ressoar sem significação, apostando no porvir sem futuro e em um presente que não tem mais lugar nos despojos de uma língua que se dividiu, que se espalhou por várias direções, levando os homens ainda inebriados para diferentes lugares do mundo até o momento em que se espera o retorno da primeira língua - a absolvição do castigo divino.

Em relação à festa dionisíaca, o narrador, observando a multidão em transe, rejeita prontamente a possibilidade de interagir com o restante dos homens, uma vez que não lhe interessava o primitivo dado por Dionísio. Além de não poder ser possível a racionalização da embriaguez, esse retorno não traria a possibilidade de se reverter a falta cometida pelos homens do antes-Babel. Em sua perspectiva, a festividade era apenas uma consequência da queda da torre, queda da lei, e não uma possibilidade de reconciliação definitiva com o Divino. Ao desejar ainda a restauração da ordem, resistindo aos mistérios da natureza, Sophonie passa a ser o seu contraponto, aquela que, sem Deus, passa a ser uma bacante arrebatada por Baco, desaparecendo, assim, das vistas do narrador. Mas, antes de se juntar à multidão, diz Sophonie ao narrador:

- Não compreendo suas preocupações, ela dizia. Você não sentia, durante o cortejo, que boa vida se podia ainda levar aqui? Enquanto nós descíamos as ruas, retirei meus sapa-

18 "Avec des débris de paroles, comme si du langage n'eussent subsité que les formes d'une longue phrase écrasée par le piétinement de la foule, on modula le chant d'un mot qui transparaissait à travers n'importe quel hurlement. Ce mot était jusqu’à ce que." 
tos, me deixei arrastar pela multidão que me encobria, me pressionava. Seus gritos, vindos de muito baixo, me atravessavam o corpo, subindo até a minha boca. Eu falava sem dizer uma palavra. (BLANCHOT, 1983: 64) ${ }^{19}$

Com a multidão em desordem, a noite estava cada vez mais próxima de consumir a cidade, de selar o castigo da confusão das línguas. Em seu passeio pelas ruas tumultuadas, sempre na companhia dos cães que o vigiavam, o narrador se depara com um pavilhão no qual estavam resguardados os mais jovens habitantes da cidade, as crianças: "Nesse pavilhão estavam encerradas as crianças mais jovens da cidade, aquelas que somente consentem em falar gritando e chorando." (BLANCHOT, 1983: 66) ${ }^{20}$.

Ao se aproximar das crianças, o narrador se aproxima do primitivo que elas resguardam no olhar, reconhecendo através da retina do infante a si mesmo como aquele que participa de um primitivo tardio, falante de uma outra linguagem, a linguagem do balbucio, do grito, linguagem que o acomoda na particularidade da primeira língua que se perdeu na queda da primeira Babel: "Sou, eu também, uma criança no berço e tenho necessidade de falar por gritos e lágrimas. Façamos a paz." (BLANCHOT, 1983: 67) ${ }^{21}$.

A relação que o narrador estabelecerá com as crianças é, sobretudo, uma relação que lhe propiciará uma interação maior com o elemento noturno, passando a enxergar o mundo a partir da clarividência trazida pela noite, o mundo tornado noite: "- Sim, disse, você também, você vê esse maldito sol que queima e não ilumina." (BLANCHOT, 1983: 76) ${ }^{22}$.

O sol deixa de ter a seguridade que antes representava - não há mais possibilidade de saída. A noite se estabelece definitivamente na narrativa blanchotiana. $\mathrm{O}$ narrador, na presença do primitivo/criança, se deixa abraçar por elas, como se abraçasse aquele que nós reconhecemos como parte de nossa comunidade, como se todos ali fossem partidários de um primitivo que não poderá ser mais restituído: "a comunidade não é somente a comunicação íntima entre si de seus membros, mas também a comunhão orgânica dela mesma com sua própria essência." (NANCY, 2011: 30 23. Com os olhares direcionados para o céu escuro, os infantes atestavam a vinda do castigo que acompanhava a noite. Clarividência compartilhada, logo mais, pelo narrador.

19 “- Je ne comprends pas vos préoccupations, disait-elle. Ne sentiez-vous pas, pendant le cortège, quelle bonne vie on peut encore mener ici? Tandis que nous descendions les rues, j'ai retiré mes chaussures, je me suis laissée entraîner par la foule qui m’enveloppait, me pressait. Ses cris, venus de très bas, me traversaient le corps, remontaient jusqu'à ma bouche. Je parlais sans avoir à dire un mot."

20 "Dans ce pavillon étaient enfermés les plus jeunes enfants de la ville, ceux qui ne consentent à parler qu'en criant et pleurant."

${ }_{21}$ "Je suis, moi aussi, un enfant au berceau et j’ai besoin de parler avec des cris et des larmes. Faisons la paix." 22 "- Oui, dis-je, vous aussi, vous voyez ce maudit soleil qui brûle et n'éclaire pas."

${ }_{23}$ "la communauté n'est pas seulement la communication intime de ses membres entre eux, mais aussi la communion organique d'elle-même avec sa propre essence.” 
Do contato com o primitivo, o personagem, já recolhido em uma torre perto da cidade, entra num estado de transe que culminará numa visão apocalíptica daquela localidade, balbuciando palavras desarrazoadas, sentindo o seu corpo se modificar, olhando a particularidade do mundo através de uma perspectiva aterradora, sem possibilidade de salvação ou de continuidade para os homens que ainda ali permaneciam: "Dali, a visão se estendia até sobre a esplanada, onde se viam corpos estendidos sobre macas; era a hora mais próxima da noite; os infelizes, atormentados, sofriam do que eles acreditavam ser um remédio para curá-los e eles estavam esmagados pela vergonha que os jogava entre os braços de um salvador." (BLANCHOT, 1983: 75, grifos meus) ${ }^{24}$. Salvador que não viria para ajudá-los, claro, mas para lhes apresentar a temeridade do espaço da noite, a impossibilidade de salvação e o caráter impossível de se (re)começar o que não possui mais começo.

Em sua vinda, o messias repetirá a queda de Babel, ratificando, por uma segunda vez, o impossível da origem e da restituição da ordem. O resultado da visão clarividente do narrador se assemelha ao resultado obtido por outro personagem blanchotiano, da narrativa La folie du jour, que teve os olhos feridos por cacos de vidro: "Com o tempo, fiquei convencido que via face a face a loucura do dia; tal era a verdade: a luz se tornava louca, a claridade tinha perdido todo bom senso; ela me assaltava sem razão, sem regra, sem objetivo.” (BLANCHOT, 2002: 19) ${ }^{25}$.

Em "Le dernier mot", a visão do narrador, assim como a do outro personagem blanchotiano, é atingida por ele saber demais, por ele não permanecer na interrogação superficial dos fatos que já estavam comumente dispostos, por ele preferir a interioridade das coisas ao seu caráter mais trivial: "Parecia-me que meus olhos enfim estavam fechados. Eles me queimavam, não via nada; eles me consumiam e essa queimadura me dava a felicidade de estar cego." (BLANCHOT, 1983: 77)26.

Antes de ter a visão apocalíptica da destruição da cidade, o narrador, logo após ter saído do pavilhão das crianças, esbarra em uma possível bacante no meio de uma estrada de pedra: "Era um deserto onde às vezes passeavam mulheres embriagadas. [...] Mas, alguns passos mais longe, tropecei contra um corpo e parei." (BLANCHOT, 1983: 72) 27.

Como é sabido entre aqueles que conhecem os rituais dionisíacos, as mulheres embriagadas possuíam o dom da clarividência: "Ele é um demônio mântico: baqueu/ e demente têm vínculo com mântica./ Quando o divino adentra fundo o corpo,/ faz dizer o futuro a quem delira." (EURÍPEDES, 2010: 62) Esse dom permitiu à desconhecida prever o que excedia da figura do narrador, o seu lado cada vez mais primitivo, arraigado à noite. E, sobretudo, ela previu a inscrição valiosa

\footnotetext{
${ }_{24}$ “De là, la vue s'étendait jusque sur l'esplanade, où l’on voyait des corps étendus sur des civières; c'était l'heure la plus proche de la nuit; les malheureux, tourmentés, souffraient de ce qu'ils croyaient un remède pour les guérir et ils étaient écrasés par la honte qui les jetait entre les bras d'un sauveur."

25 "À la longue, je fus convaincu que je voyais face à face la folie du jour; telle était la vérité: la lumière devenait folle, la clarté avait perdu tout bon sens; elle m'assaillait déraisonnablement, sans règle, sans but.”

26 "Il me semblait que mes yeux enfin s'étaient fermés. Ils me brûlaient, je ne voyais rien; ils me consumaient et cette brûlure me rendait le bonheur d'être aveugle."

${ }_{27}$ "C'était un désert où parfois se promenaient des femmes ivres. [...] Mais, quelques pas plus loin, je butai contre un corps et m'arrêtai.”
} 
que estava talhada em seu corpo. Uma previsão de futuro que escapava até mesmo dele: "Graças à embriaguez, ela me via tal qual eu era." (BLANCHOT, 1983: 72)28

Do encontro, os dois personagens partilham a intimidade do sexo: "Desenrolei a largueza do tecido com o qual ela se cobria e, me recolhendo com ela dentro dele, me tornei durante alguns instantes um homem de uma outra cidade." (BLANCHOT, 1983: 73) ${ }^{29}$ No texto de "Le dernier mot", o sexo não se apresenta apenas como fator originado do desejo orgiástico que ainda imperava na bacante, mas se apresenta principalmente como fator que evidenciava o estado transitório no qual se encontrava o narrador. A sua transitoriedade perpassa desde a visão apocalíptica da cidade até o desfecho arrebatador da última inscrição de uma linguagem em seu corpo. Após o momento íntimo, o casal decide se abrigar em uma grande torre, localizada fora dos contornos da cidade. Fortaleza desconhecida, assim como a lista de presença, assim como a cidade e assim como a época em que a narrativa se desenvolve. Tudo, ou quase tudo, é omitido pela noite.

Instalados na torre, enquanto o narrador estava possuído pelas visões noturnas, a jovem, em outro ambiente, começava a se queixar das dores provocadas por sucessivas queimaduras em seu corpo. A personagem, não mais aguentando a dor provocada pelas lesões, vai em direção ao chamado do narrador, aproveitando a oportunidade para relatar as queimaduras. Ao se despir para que o personagem averiguasse a extensão das lesões e a razão de sua causa, as primeiras formas de uma escrita original estavam talhadas em seu corpo - todo um alfabeto se oferecia à exibição através dos seus ferimentos: "Gritei, chamei essa moça. 'Meu corpo está queimando', a jovem disse. Ela entreabriu seu casaco e me mostrou as manchas de fogo que desenhavam ali as primeiras formas de uma vaga linguagem." (BLANCHOT, 1983: 76) ${ }^{30}$.

O corpo ferido da personagem apresentava uma linguagem original, inscrita de forma rudimentar, talhada pelo fogo manual/corporal do casal - corpo talhado primitivamente. De suas feridas, pulsava ainda o instrumento que gravara em seu corpo o arcabouço de uma nova linguagem. Na verdade, a linguagem original já estava esculpida no corpo do narrador, carecendo da fúria dos corpos, ou melhor, carecendo do outro para tornar-se, pois para que exista linguagem é preciso que exista o diálogo, que exista o outro, o corpo do outro. A funcionalidade da linguagem somente pode ser fundada através do outro - quando interpelo o outro: "Quando falo ao outro, eu faço um apelo a ele. Antes de tudo, a palavra é esta interpelação, esta invocação [...]." (BLANCHOT, 2001: 103).

O narrador, por ser aquele que trazia uma nova linguagem em seu corpo, foi dado como o último. $\mathrm{O}$ último homem que poderia oferecer à humanidade a concepção de uma nova linguagem. O salvador que daria ao homem um novo alfabe-

28 "Grâce à l'ivresse, elle me voyait tel que j'étais."

29 "Je déroulai l'ampleur de l'étoffe dans laquelle elle s'enveloppait et, m'y enfermant avec elle, je devins pendant quelques instants un homme d'une autre ville."

${ }_{30}$ "Je criai, j'appelai cette fille. 'Mon corps brûle', dit celle-ci. Elle entrouvrit son manteau et me montra les taches de feu qui y dessinaient les premières formes d'un vague langage." 
to, sílabas que uniriam a todos, morfemas que aplacariam o castigo, dando uma nova oportunidade aos descendentes daqueles que desejaram construir a primeira Babel. Deus estaria cansado do desentendimento secular. Ele estaria disposto a fazer as pazes com a sua criatura.

Contudo, agora, é tarde demais. A noite já conquistou o todo do território discursivo blanchotiano. A noite consome os ébrios da cidade, esperando ser aclamada pelos homens como o novo salvador. Nos momentos finais da narrativa de "Le dernier mot", todos já sentem o odor de maresia provindo do subterrâneo da cidade. Deus, como uma criança pérfida, concedeu ao homem, por instantes, a esperança de uma nova linguagem - linguagem da absolvição. No entanto, esperança que somente existiu enquanto esperança. Deus, na verdade, não o perdoou: "Busquem a justiça, busquem a humildade, talvez vocês tenham abrigo no dia da ira do Senhor." (SOFONIAS, v.2.3: 1.565).

Do lado de fora da torre, onde o narrador, a jovem bacante e um terceiro personagem estavam abrigados, uma multidão ébria a balançava com uma força sobre-humana, instigada pelas alucinações provindas da noite. Deus nada fez para ajudá-los. Os ébrios somente pararam quando a última pedra da torre caiu. E com os escombros da torre caíram o narrador e a esperança de uma vaga linguagem. Desaparecendo, assim, a possibilidade de retorno à origem.

A luminosidade do dia se extinguiu.

A obscuridade da noite ascendeu: "Ela experimentou abrir a porta, mas um barulho apavorante balançou a torre. / - Ai! ela disse, não sente que o chão nos falta? / Mas ele a acalmou por sua tranquilidade, e, quando a queda da torre os precipitou para fora, eles caíram todos os três sem dizer uma palavra." (BLANCHOT, 1983: 81) ${ }^{31}$.

Do barulho da precipitação das pedras e dos corpos se ouviu um silêncio ensurdecedor.

A noite chegou definitivamente na cidade sem nome de "Le dernier mot" e com ela o castigo definitivo.

Babel, mais uma vez, sucumbiu.

\section{REFERÊNCIAS BIBLIOGRÁFICAS:}

BÍBLIA DE ESTUDO NVI/ organizador geral Kenneth Barker; co-organizadores Donald Burdick... [et al.]. São Paulo: Editora Vida, 2003.

BLANCHOT, Maurice. L'Écriture du désastre. Paris: Gallimard, 1980.

${ }_{31}$ "Elle essaya d'ouvrir la porte, mais un bruit épouvantable ébranla la tour. / - Hélas! dit-elle, ne sentezvous pas que le sol nous manque? / Mais il la rassura par sa tranquillité, et, quand la chute de la tour les précipita au-dehors, ils tombèrent tous trois sans dire un mot." 
Après coup précédé par Le ressassement éternel. Paris: Les Éditions de Minuit, 1983.

A Conversa infinita 1: A Palavra plural. Tradução de Aurélio Guerra Neto. São Paulo: Escuta, 2001.

. La Folie du jour. Paris: Gallimard, 2002.

A Conversa infinita 2: A Experiência limite. Tradução de João Moura Jr. São Paulo: Escuta, 2007.

CAMUS, Albert. Caligula. Paris: Gallimard, $195^{8}$.

DERRIDA, Jacques. Donner la mort. Paris: Galilée, 1999.

Torres de Babel. Tradução de Junia Barreto. Belo Horizonte: Editora UFMG, 2002.

EURÍPEDES. As Bacantes de Eurípedes. Tradução de Trajano Vieira. São Paulo: Perspectiva, 2010.

NANCY, Jean-Luc. La Communauté désœuvrée. Paris: Christian Bourgois éditeur, 2011.

NIETZSCHE, Friedrich. O Nascimento da tragédia ou helenismo e pessimismo. Tradução de J. Guinsburg. São Paulo: Companhia das Letras, 2007. 